\title{
Detection and molecular characterization of tomato yellow leaf curl virus naturally infecting Lycopersicon esculentum in Egypt
}

\author{
M. RABIE ${ }^{1}$, C. RATTI², E. ABDEL ALEEM ${ }^{1}$, F. FATTOUH ${ }^{1}$
}

${ }^{1}$ Botany and Microbiology, Department Faculty of Science, Alexandria University, Alexandria, Egypt; ${ }^{2}$ DipSA-Patologia Vegetale, Università di Bologna, Viale G. Fanin, 40-40127 Bologna, Italy

Received September 30, 2016; revised November 7, 2016; accepted June 5, 2017

\begin{abstract}
Summary. - Tomato yellow leaf curl virus (TYLCV) infections of tomato crops in Egypt were widely spread in 2014. Infected symptomatic tomato plants from different governorates were sampled. TYLCV strains Israel and Mild (TYLCV-IL, TYLCV-Mild) were identified by multiplex and real-time PCR. In addition, nucleotide sequence analysis of the V1 and V2 protein genes, revealed ten TYLCV Egyptian isolates (TYLCV from TY1 to 10). Phylogenetic analysis showed their high degree of relatedness with TYLCV-IL Jordan isolate (98\%). Here we have showed the complete nucleotide sequence of the TYLCV Egyptian isolate TY10, sampled from El Beheira. A high degree of similarity to other previously reported Egyptian isolates and isolates from Jordan and Japan reflect the importance of phylogenetic analysis in monitoring virus genetic diversity and possibilities for divergence of more virulent strains or genotypes.
\end{abstract}

Keywords: multiplex PCR; real-time PCR; TYLCV-IL; TYLCV-Mild; phylogenetic analysis

\section{Introduction}

Tomato yellow leaf curl disease (TYLCD) is a serious threat to tomato production in many areas of the world. Yield losses near to $100 \%$ were in geographically diverse locations such as central Southeast Asia, the Far East Asia, USA, Caribbean islands, Tropical Africa and several Mediterranean countries (Czosnek and Laterrot, 1997; Nakhla and Maxwell, 1998; Moriones and Navas-Castillo, 2000; Ueda et al., 2004; Rojas et al., 2007; Brown and Idris, 2008). In Egypt, it was first reported in 1969 (Nour El-din et al., 1969) and caused several losses in tomato yields in 1991 (Nakhla et al., 1993). The disease is continuing to cause epidemics that are devastating tomato crops widely and rapidly. TYLCD is caused by a complex of several virus species, belonging to the genus Begomovirus, transmitted by the whitefly Bemisia tabaci in a circulative and persistent manner. Begomovirus is one of four genera in the family Geminiviridae compris-

E-mail: mona_rabie55@yahoo.com; phone:+2-01063703444. Abbreviations: TYLCD = tomato yellow leaf curl disease; TYLCV $=$ tomato yellow leaf curl virus ing viruses with circular single stranded DNA genome and tomato yellow leaf curl virus (TYLCV) is the most wide spread species in tomato plants.

The genome of TYLCV contains six partially overlapping open reading frames (ORFs) bidirectionally arranged into two transcriptional units that are separated by an intergenic region of approximately 300 nucleotides, containing motifs for viral genome replication and transcription (Rybicki et al., 2000). V1 encoding a coat protein, and V2 encoding a pre-coat protein that acts as a suppressor of RNA silencing are partially overlapping genes (Glick et al., 2008; Jiang et al., 2012). The product of the complementary C1 ORF is the only virus-encoded protein replicase or replication initiator (Rep) which plays the key role in initiating the rolling circle replication by virtue of its nicking and ligation property (Arupratan et al., 2004). The C3 protein, the gemini viral replication enhancer (REn) protein is able to increase viral DNA accumulation and enhance infectivity and symptoms expression (Hormuzdi and Bisaro, 1995). The $\mathrm{C} 2$ and the $\mathrm{C} 4$ proteins were demonstrated to be suppressors of the RNAsilencing pathway (Abhary et al., 2006), while C4 induces virus-like symptoms in host plants (Selth et al., 2004). 
Factors contributing to the emergence of new variants over the years within the genus Begomovirus, have been attributed to mutation, recombination and pseudo recombination among TYLCV virus strains (Czosnek and Ghanim, 2011). Full-length genomic sequencing allows for a more comprehensive analysis of virus variability and different forces driving the evolution of TYLCV. Two strains infect tomato crops in the Middle East, tomato yellow leaf curl virus-Israel (TYLCV-IL) and tomato yellow leaf curl virus-Mild (TYLCV-Mild) strains. More recently, the strain "Spain" of another Begomovirus, the tomato yellow leaf curl Sardinia virus (TYLCSV-ES), has been identified in Jordan and Israel (Anfoka et al., 2005). To develop effective control strategy against TYLCD, it is necessary to identify the virus species or strains causing the infection. The present study aims at the identification of TYLCV infection and the study of virus species by partial and complete genome sequencing of Egyptian isolates for identification of their phylogenetic relationships with the previously reported isolates.

\section{Materials and Methods}

Collection of TYLCD-symptomatic tomato plants. Ninety Lycopersicon esculentum (tomato) leaf samples from plants showing virus related symptoms and representing different tomato cultivars were collected. Samplings were from different cultivars of tomato from selected governorates in Egypt.

Total DNA extraction. Extraction of total DNA from symptomatic and healthy tomato plants was done as described by Zhou et al. (2001). Briefly, $200 \mathrm{mg}$ of leaf tissue ground in $2 \mathrm{ml}$ of grinding buffer containing 2\% CTAB (cetyltrimethylammonium bromide), $100 \mathrm{mmol} / \mathrm{l}$ Tris-HCl, pH 8, $20 \mathrm{mmo} / \mathrm{l}$ EDTA, $1.4 \mathrm{~mol} / \mathrm{l} \mathrm{NaCl}, 1.0 \%$ sodium sulphite and 2\% PVP- 40 . After incubation at $65^{\circ} \mathrm{C}$ for 15 $\mathrm{min}$, an equal volume of chloroform/isoamyl alcohol (24:1) was added and centrifuged at maximum speed for $15 \mathrm{~min}$ for 2 times. Two hundred $\mu \mathrm{l}$ of $4 \mathrm{~mol} / \mathrm{l} \mathrm{NaCl}$ and $300 \mu \mathrm{l}$ of iso-propanol was added to aqueous layer, mixed, and incubated at $-20^{\circ} \mathrm{C}$ for $1 \mathrm{~h}$. Samples were centrifuged at maximum speed for $30 \mathrm{~min}$ at $4^{\circ} \mathrm{C}$ to pellet the DNA, washed with $70 \%$ ethanol and resuspended in $100 \mu$ of nuclease-free $\mathrm{H}_{2} \mathrm{O}$. Total DNA was stored at $-20^{\circ} \mathrm{C}$ until use for PCR analysis.

Detection of TYLCV. The presence of TYLCV has been proved in DNA extracts of L. esculentum by using primers TYLCV-TY1F, TYLCV-TY2R (Accotto et al., 2000), that amplify a region of $579 \mathrm{nts}$ from the coat protein (CP) gene (Table 1). PCR reaction was done in a total volume of $25 \mu$ l. Viral DNAs were amplified by PCR in a reaction mixture containing $5 \mu \mathrm{l}$ of $5 \mathrm{x} \mathrm{Mg}$-free buffer, $3 \mu \mathrm{MgCl}_{2}$ $25 \mathrm{mnol} / \mathrm{l}, 1 \mu \mathrm{l}(5 \mathrm{nmol} / \mathrm{ml}$ ) of each primer (TYLCV-TY1F, TYLCV -TY2R), $0.5 \mu \mathrm{l}$ dNTP mix (10 mmol/l), $0.2 \mu \mathrm{l}$ of $5 \mathrm{U} / \mu \mathrm{l} \mathrm{GoTaq}{ }^{\oplus} \mathrm{G} 2$ DNA polymerase (Promega, USA) and $1 \mu \mathrm{l}$ of the extracted DNA. PCR cycle parameters are described in Table 1. Products were visualized in $1 \%$ agarose gel by electrophoresis.
Molecular identification of TYLCV strains by multiplex PCR. Two sets of previously published primers (Anfoka et al., 2008) detect and differentiate TYLCSV-ES, TYLCV-IL, TYLCV-Mild and tomato yellow leaf curl Sardinia virus-Sicily (TYLCSV-Sic) in symptomatic tomato plants. The first set includes TYAlmv2516 - TYAlmc115 pair that specifically detects TYLCSV-ES (but not other strains of TYLCSV species) and TYv2337, TYc138, and TYv2664 primers that differentiate between TYLCV-IL and TYLCV-Mild (Anfoka et al., 2005). The second set includes RVC427, VP2715 and Sa2267 primers, designed to detect all strains of TYLCSV, including the Italian TYLCSV-IT, the Sicilian TYLCSV-Sic and the Spanish (TYLCSVES) strains, was used to detect TYLCV and TYLCSV (Anfoka et al., 2008). The sequence of each primer as well as the PCR cycle parameters are described in Table 1. In particular, PCR reactions were optimized in a final volume of $25 \mu \mathrm{l}$ containing: $0.5 \mu \mathrm{dNTP}$ $\operatorname{mix}(10 \mathrm{mmol} / \mathrm{l}), 5 \mu \mathrm{l}$ of $5 \mathrm{x} \mathrm{Mg}$-free buffer, $3 \mu \mathrm{lgCl}_{2} 25 \mathrm{mmol} / \mathrm{l}$, 1 unit of GoTaq ${ }^{\oplus}$ G2 DNA polymerase $(0.2 \mu \mathrm{l})$ (Promega), $1 \mu \mathrm{l}$ of each primer $(10 \mu \mathrm{mol} / \mathrm{l})$ and $1 \mu \mathrm{l}$ of DNA template.

Real-time RT-PCR for detection and differentiation of Israel and Mild TYLCV strains. In order to design a primer pair able to identify TYLCV in plant tissue and also differentiate the presence of IL and Mild strains of the virus, a multiple sequence alignment of TYLCV complete genomes available at the GenBank database using Geneious 7.0.6 software package was done. Primers TYLCV $2234 \mathrm{~F}$ and TYLCV 2537R (Table 1 and Fig. 1) targeting regions conserved within both two strains and flanking a 324 bp region (covering partial ORFs $\mathrm{C} 1$ and $\mathrm{C} 4$ ) that differs IL and Mild isolates. Real-time RT-PCR reaction was performed in a total volume of $20 \mu$ containing: $10 \mu \mathrm{l}$ of $2 \mathrm{x} \mathrm{GoTaq}^{\circledR} \mathrm{qPCR}$ master mix (Promega), $2 \mu \mathrm{l}$ of $10 \mathrm{mmol} / \mathrm{l} \mathrm{dNTP} \operatorname{mix}$ (Promega), $0.17 \mu \mathrm{l}$ of $30 \mu \mathrm{mol} / \mathrm{l} \mathrm{CXR}$ (carboxy-X-rhodamine reference dye), $1 \mu \mathrm{l}$ each of $10 \mu \mathrm{mol} / \mathrm{l}$ TYLCV $2234 \mathrm{~F}$ and TYLCV 2537R primers and $0.5 \mu \mathrm{l}$ of DNA. The reaction was carried out in an ABI Prism 7000 System (Applied Biosystems) using program parameters described in Table 1.

Sequence analysis of $V 1+V 2$ genes and full-length genome of TYLCV Egyptian isolates. Primers designed from gene sequences of different TYLCV isolates were obtained from the GenBank database. The Clustal W 1.8 (BCM search launcher) was applied for multiple sequence alignments of each of the coat protein (V1) gene and the movement protein (V2) gene. The V2 and V1 sequences were conserved in most aligned sequences. The primer pairs TYLCV V2 F/ TYLCV V1 R2 and TYLCV FL F/ TYLCV FL R were designed to amplify $\mathrm{V} 2+\mathrm{V} 1$ and full length sequences of TYLCV, respectively (Table 1 and Fig. 1). PCR reaction was performed in a total volume of $25 \mu \mathrm{l}$ using $12.5 \mu \mathrm{l}$ of GoTaq ${ }^{\circledR}$ long PCR master mix (Promega), $1 \mu \mathrm{l}$ of each primer $(5 \mathrm{nmol} / \mathrm{ml})$ and $1 \mu \mathrm{l}$ of the DNA sample. PCR cycle parameters as described in Table 1 were used. To determine the sequence of the amplified fragments, DNA was purified from excised bands from agarose gel using the Wizard ${ }^{\circledR}$ SV gel PCR clean-up system kit (Promega), ligated into pGEM T- easy vector (Promega) and cloned in Escherichia coli MC1022 competent cells. Extraction of recombinant plasmid DNA was done with the Wizard ${ }^{\circ}$ Plus SV minipreps DNA purification system (Promega) and the sequences of the 
Table 1. Description of primers and PCR conditions used for the amplification of TYLCV genome

\begin{tabular}{|c|c|c|c|c|c|c|c|}
\hline References & PCR cycling conditions & $\begin{array}{l}\text { Target } \\
\text { region }\end{array}$ & $\begin{array}{l}\text { Expected } \\
\text { product } \\
\text { size }(b p)\end{array}$ & $\begin{array}{l}\text { Nucleotide } \\
\text { position }\end{array}$ & Sequence $\left(5^{\prime}\right.$ to $\left.3^{\prime}\right)$ & Primers & \\
\hline \multirow[t]{3}{*}{$\begin{array}{l}\text { Anfoka et al., } \\
2005\end{array}$} & $\begin{array}{l}94^{\circ} \mathrm{C} / 2 \mathrm{~min}, 30 \times 94^{\circ} \mathrm{C} / 1 \mathrm{~min}, \\
62^{\circ} \mathrm{C} / 45 \mathrm{~s}, 72^{\circ} \mathrm{C} / 1 \mathrm{~min}, \\
72^{\circ} \mathrm{C} / 10 \mathrm{~min}\end{array}$ & IR & 432 & $\begin{array}{c}122-150^{\mathrm{a}} \\
2496-2523^{\mathrm{a}}\end{array}$ & $\begin{array}{l}\text { ATATTGATGGTTTTT } \\
\text { TCAAAACTTAGAAG } \\
\text { TTTTATTTGTTGGTGTTTG } \\
\text { TAGTTGAAG }\end{array}$ & $\begin{array}{l}\text { TYAlmc115 } \\
\text { TYAlmv } 2516\end{array}$ & \\
\hline & & IR & 633 & $\begin{array}{c}2311-2337^{\mathrm{b}} \\
138-162^{\mathrm{b}}\end{array}$ & $\begin{array}{l}\text { ACGTAGGTCTTGACATCT } \\
\text { GTTGAGCTC } \\
\text { AAGTGGGTCCCACATATT } \\
\text { GCAAGAC }\end{array}$ & $\begin{array}{l}\text { TYv2337 } \\
\text { TYc138 }\end{array}$ & \\
\hline & & IR & 314 & $\begin{array}{c}18-44^{\mathrm{c}} \\
307-331^{\mathrm{c}}\end{array}$ & $\begin{array}{l}\text { ATTGACCAAGATTTTTA } \\
\text { CACTTATCCC } \\
\text { AAGTGGGTCCCACATATT } \\
\text { GCAAGAC }\end{array}$ & $\begin{array}{l}\text { TYv2664 } \\
\text { TYc138 }\end{array}$ & " \\
\hline \multirow[t]{2}{*}{$\begin{array}{l}\text { Anfoka et al., } \\
2008\end{array}$} & $\begin{array}{l}95^{\circ} \mathrm{C} / 3 \mathrm{~min}, 40 \times 94^{\circ} \mathrm{C} / 3 \\
\min , 52^{\circ} \mathrm{C} / 30 \mathrm{~s}, 72^{\circ} \mathrm{C} / 1 \mathrm{~min} \\
2^{\circ} \mathrm{C} / 10 \mathrm{~min}\end{array}$ & IR & 927 & $\begin{array}{c}2268-2293^{\mathrm{d}} \\
398-421^{\mathrm{d}}\end{array}$ & $\begin{array}{l}\text { TGGAAAGTACCCCATTCAA } \\
\text { GAACATC } \\
\text { TGCCTTGGACART } \\
\text { GGGGRCAGCAG }\end{array}$ & $\begin{array}{l}\text { Sa2267 } \\
\text { RVC427 }\end{array}$ & \\
\hline & $\begin{array}{l}95^{\circ} \mathrm{C} / 3 \mathrm{~min}, 40 \times 94^{\circ} \mathrm{C} / 3 \\
\min , 52^{\circ} \mathrm{C} / 30 \mathrm{~s}, 72^{\circ} \mathrm{C} / 1 \mathrm{~min}, \\
72^{\circ} \mathrm{C} / 10 \mathrm{~min}\end{array}$ & IR & 528 & $\begin{array}{c}61-87^{\mathrm{e}} \\
565-588^{\mathrm{e}}\end{array}$ & $\begin{array}{l}\text { ATACTTGGACACCTAAT } \\
\text { GGCTATTTGG } \\
\text { TGCCTTGGACART } \\
\text { GGGGRCAGCAG }\end{array}$ & $\begin{array}{l}\text { VP2715 } \\
\text { RVC427 }\end{array}$ & $\stackrel{2}{\mathbb{E}}$ \\
\hline $\begin{array}{l}\text { Accotto et } \\
\text { al., } 2000\end{array}$ & $\begin{array}{l}94^{\circ} \mathrm{C} / 3 \mathrm{~min}, 35 \times 94^{\circ} \mathrm{C} / 30 \mathrm{~s} \\
60^{\circ} \mathrm{C} / 30 \mathrm{~s}, 72^{\circ} \mathrm{C} / 30 \mathrm{~s}, 72^{\circ} \mathrm{C} / 7 \\
\min \end{array}$ & $\mathrm{CP}$ & 579 & $\begin{array}{c}447-464^{\mathrm{d}} \\
1007-1025^{\mathrm{d}}\end{array}$ & $\begin{array}{l}\text { GCCCATGTAYCGRAAGCC } \\
\text { GGRTTAGARGCATGMGTAC }\end{array}$ & $\begin{array}{l}\text { TYLCV-TY1F } \\
\text { TYLCV-TY2R }\end{array}$ & \\
\hline \multirow[t]{3}{*}{ This study } & $\begin{array}{l}94^{\circ} \mathrm{C} / 3 \mathrm{~min}, 35 \times 94^{\circ} \mathrm{C} / 1 \\
\min , 55^{\circ} \mathrm{C} / 30 \mathrm{~s}, 72^{\circ} \mathrm{C} / 1.5 \\
\min , 72^{\circ} \mathrm{C} / 10 \mathrm{~min}\end{array}$ & CP\&MP & 1065 & $\begin{array}{c}101-123^{\mathrm{f}} \\
1143-1165^{\mathrm{f}}\end{array}$ & $\begin{array}{l}\text { TGATTTGTCTTTATATACTT } \\
\text { GGT } \\
\text { GAGCAGTTGATCATGTATT } \\
\text { GTAT }\end{array}$ & $\begin{array}{l}\text { TYLCV V2 F } \\
\text { TYLCV V1 R2 }\end{array}$ & \\
\hline & $\begin{array}{l}50^{\circ} \mathrm{C} / 2 \mathrm{~min}, 95^{\circ} \mathrm{C} / 10 \mathrm{~s}, 40 \mathrm{x} \\
95^{\circ} \mathrm{C} / 15 \mathrm{~s}, 60^{\circ} \mathrm{C} / 1 \mathrm{~min}\end{array}$ & REP & 324 & $\begin{array}{l}2037-2064^{\mathrm{f}} \\
2340-2360^{\mathrm{f}}\end{array}$ & $\begin{array}{l}\text { TCATCTGGAACTTGAT } \\
\text { TAAAAGAWGAAG } \\
\text { CCATCCYAACAT } \\
\text { TCAGGSAGC }\end{array}$ & $\begin{array}{l}\text { TYLCV2234 F } \\
\text { TYLCV2537 R }\end{array}$ & \\
\hline & $\begin{array}{l}94^{\circ} \mathrm{C} / 5 \mathrm{~min}, 34 \times 94^{\circ} \mathrm{C} / 10 \\
\mathrm{~s}, 54^{\circ} \mathrm{C} / 10 \mathrm{~s}, 72^{\circ} \mathrm{C} / 4 \mathrm{~min}, \\
72^{\circ} \mathrm{C} / 8 \mathrm{~min}\end{array}$ & $\begin{array}{l}V 1, V 2, C 1, C 2, \\
C 3, C 4, \mathrm{IR}\end{array}$ & 2773 & $\begin{array}{l}1016-1030^{\mathrm{f}} \\
999-1015^{\mathrm{f}}\end{array}$ & $\begin{array}{l}\text { ATGCCTCTAATCCAG } \\
\text { GCGTACATGCCATATAC }\end{array}$ & $\begin{array}{l}\text { TYLCV FL F } \\
\text { TYLCV FL R }\end{array}$ & \\
\hline
\end{tabular}

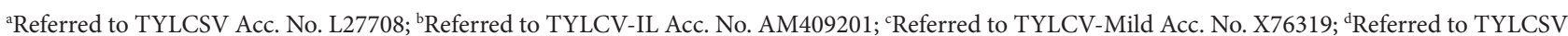

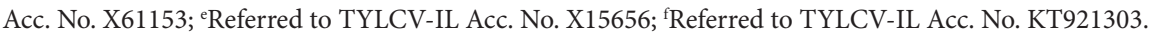

plasmid inserts were submitted to GenBank. CLUSTAL W method in MEGA 6 software (Tamura et al. 2013) generated a multiple alignments and phylogenetic trees using Bootstrap test of phylogeny (1000 replicates) under the Neighbor-Joining method. Reference sequences downloaded from GenBank database were included as representatives of TYLCV isolates (Supplementary Table S1).

\section{Results}

Detection and differentiation of TYLCD-associated viruses by conventional and real-time PCR

Using primers TYLCV-TY1F and TYLCV-TY2R we have detected 62 TYLCV infected samples. When tested by mul- tiplex PCR reactions, only amplicons of the expected sizes for TYLCV-Mild (314 bp) and TYLCV-IL (633 bp) were obtained using primer set 1 (Fig. 2a) while exclusively PCR products of $528 \mathrm{bp}$ (TYLCV-IL) were observed when primer set 2 was used for amplification (Fig. 2b). DNA extracted from healthy tomato plants was negative.

When primer pair TYLCV 2234 F/TYLCV $2537 \mathrm{R}$ was used in real-time PCR, a fluorescent signal was detected only from TYLCV-infected samples while no signal was obtained from healthy samples (Fig. 3a). Dissociation analysis of amplified products revealed two main peaks, the first one at $83.0-83.4^{\circ} \mathrm{C}$ and the second one at $85.6^{\circ} \mathrm{C}$. The reaction conducted on healthy tomato plants (Fig. 3b) showed no peaks. Sequence analysis of TYLCV $2234 \mathrm{~F} / \mathrm{TYLCV} 2537 \mathrm{R}$ amplicons (324 bp) from samples showing single or mixed 


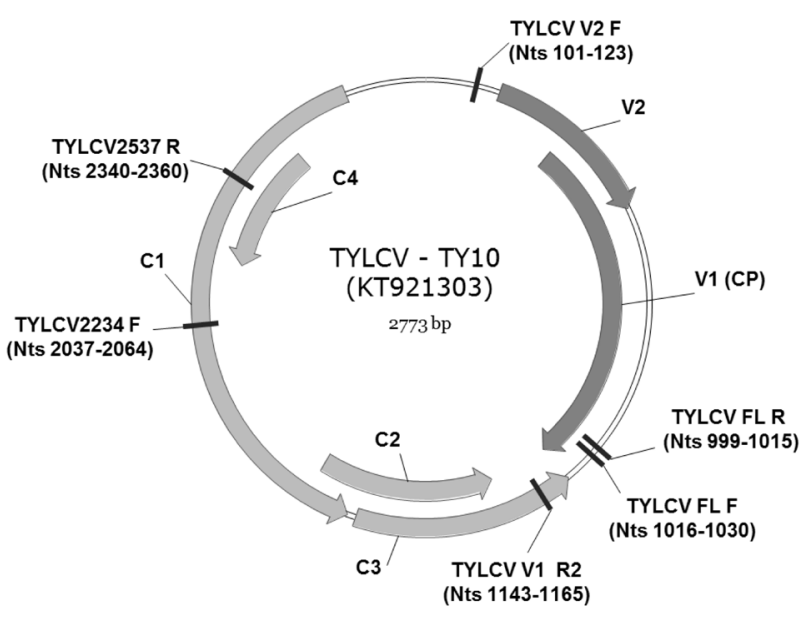

Fig. 1

Genome organization of the TYLCV TY10 Egyptian isolate (2,773 nts, Acc. No. KT921303) showing complementary (C1 to C4) and viral (V1 and V2) ORFs

Localization of primers designed and used in this study. Details of primers are in Table 1.

infection allowed to assign the peak at lower temperature $\left(83.0-83.4^{\circ} \mathrm{C}\right)$ to PCR products amplified form TYLCVIL strain and the peak at higher temperature $\left(85.6^{\circ} \mathrm{C}\right)$ to amplicons from the TYLCV-Mild strain as shown in Fig. 3b. Additional small peaks at $75.5-76.2^{\circ} \mathrm{C}$, appearing on infected samples, were not associated with any strain differentiation. Probably these are amplicons originating from some conserved region of the TYLCV genome but do not affect the results of the analysis. Using the real-time PCR assay, 65 out of 90 samples collected, were confirmed as positive for TYLCV.

\section{Incidence of TYLCD-associated viruses in Egypt}

Obtained results, revealed that the overall incidence of TYLCV infection in all governorates was $68.8 \%$ (62/90) by conventional PCR and $72.2 \%(65 / 90)$ by real-time PCR. In particular, PCR assays detected the virus in samples collected from El Sharkeya, El Qalyoubeya, Kafr El Sheikh, Giza, El Gharbeya and El Beheira governorates and not in samples from Alexandria, Damietta, El Dakahlia and El Fayoum governorates (Table 2). Results obtained using the real-time PCR assay were in complete agreement with those obtained by PCR analyses except for detection of TYLCV-IL in three samples from Kafr El Sheikh, Alexandria and El Beheira governorates that were negative in PCR reactions.

TYLCV-IL caused infection in all positive TYLCV samples. However, TYLCV-Mild was detected only in samples with mixed infection by both strains. One sample from El Sharkeya governorate, two samples from El Gharbeya and three samples from EL Giza governorate had mixed infection. Single infections with TYLCV-IL (56 samples) were prominent $(62.2 \%)$, when compared with mixed infected (TYLCV-IL + TYLCV-Mild) samples (6.6\%). There was no

(a)

$\begin{array}{llllllllllllllllllll}M & 1 & 2 & 3 & 4 & 5 & 6 & 7 & 8 & 9 & 10 & 11 & 12 & 13 & 14 & 15 & 16 & 17 & 18 & \text { H }\end{array}$

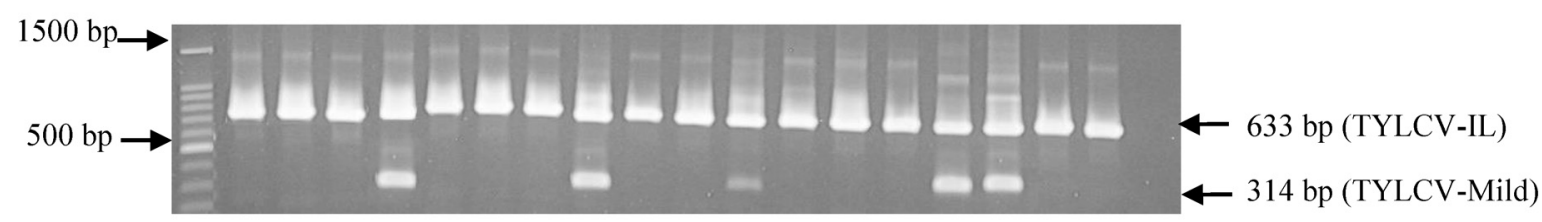

(b) $\begin{array}{llllllllllllllll}\text { M } & 19 & 20 & 21 & 22 & 23 & 24 & 25 & 26 & 27 & 28 & 29 & 30 & 31 & 32 & \text { H }\end{array}$

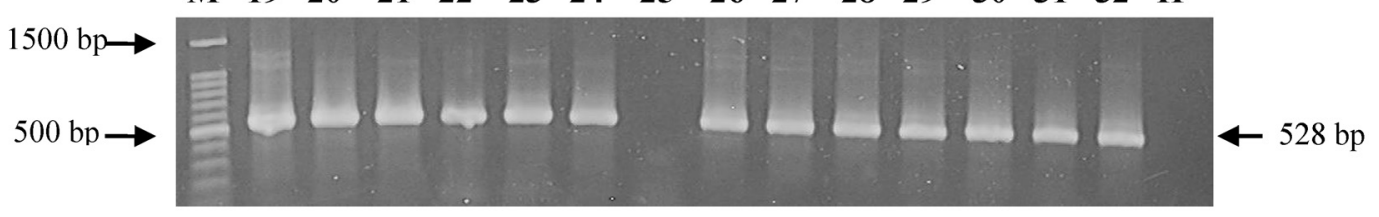

Fig. 2

Identification of TYLCD-associated viruses in symptomatic tomato plants collected from different governorates in Egypt The agarose gels stained by ethidium bromide show PCR products (TYLCV-Mid 314 bp; TYLCV-IL 633 bp) obtained using (a) primer set 1 (TYv2337, TYc138, TYv2664, TYAlmv2516, 440 and TYAlmc115) and (b) primer set 2 (Sa2267, VP2715 and RVC427). Lane H: DNA extracted from healthy tomato plants. Lane M: 100 bp DNA marker (Promega). 
(a)

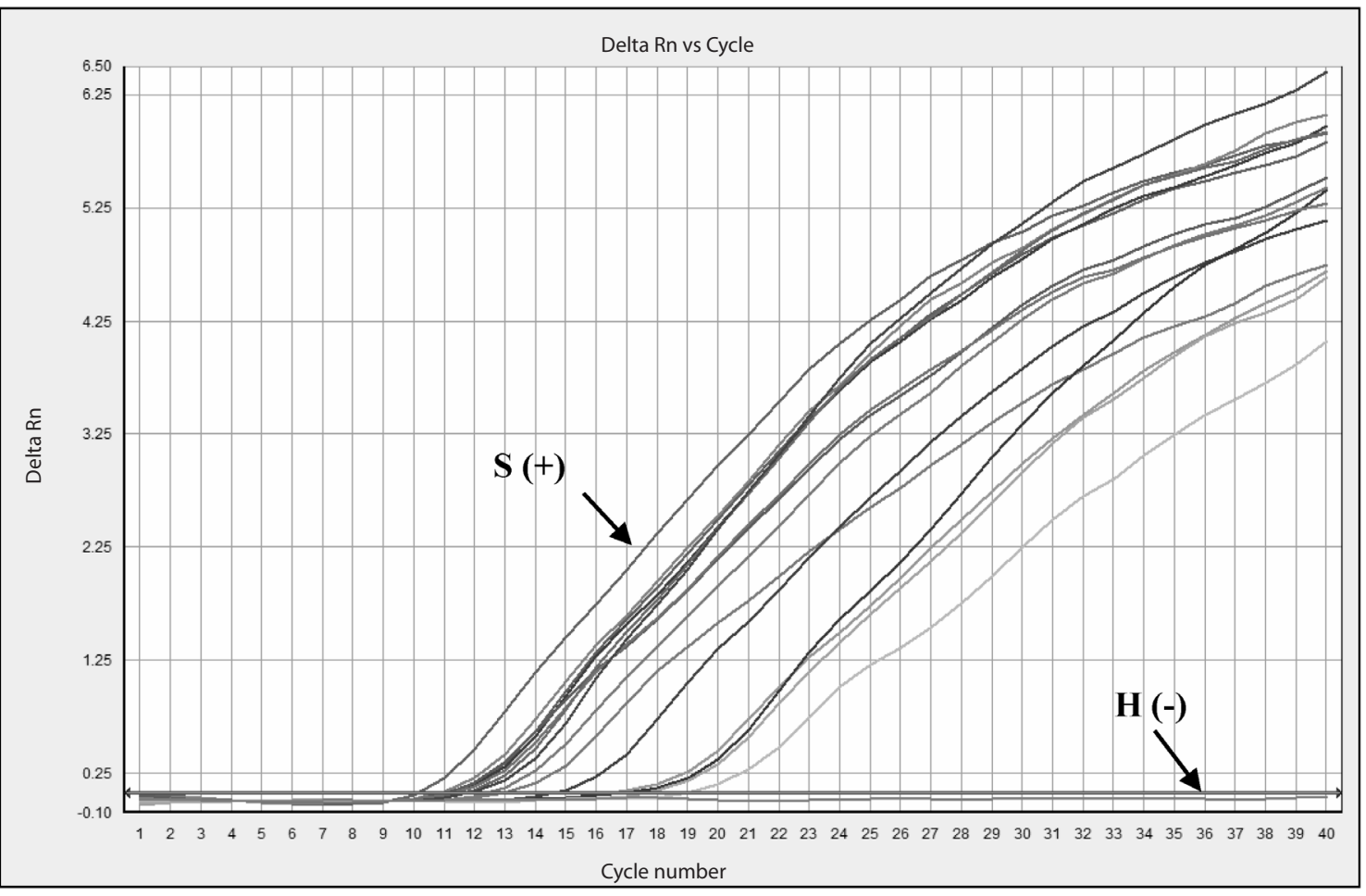

(b)

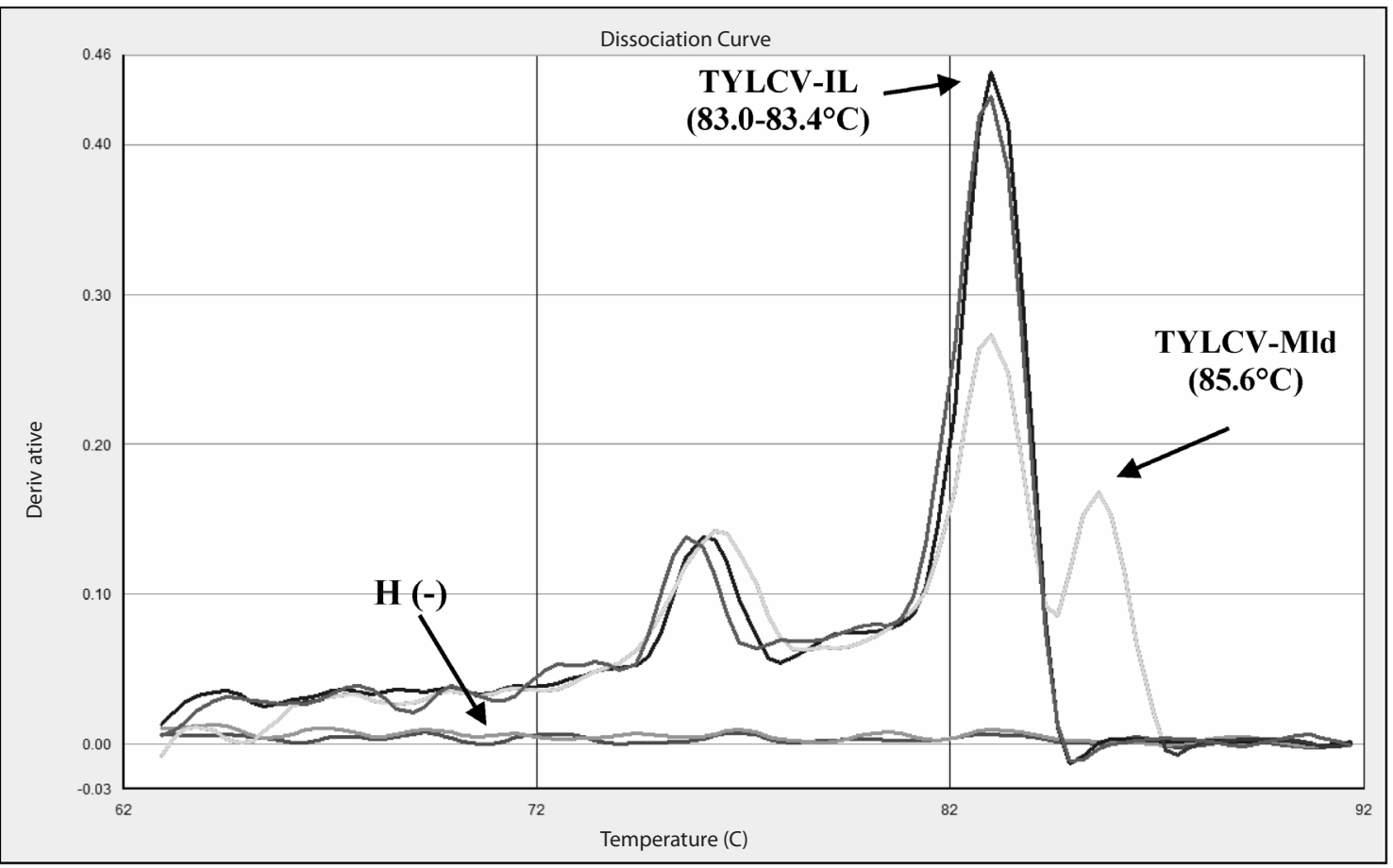

Fig. 3

Molecular detection and characterization of TYLCV-IL and TYLCV-Mild by real-time RT-PCR

(a) Amplification plot of DNA extracted from positive samples $[\mathrm{S}(+)]$ and healthy tomato plant $[\mathrm{H}(-)]$. (b) Dissociation analysis of amplified products allows to identify TYLCV-IL strain by a single peak $\left(\mathrm{Tm}=83.0-83.4^{\circ} \mathrm{C}\right)$ while TYLCV-IL + TYLCV-Mild mixed infection by an additional peak with $\mathrm{Tm}=85.6^{\circ} \mathrm{C}$. No peaks were observed from reaction conducted on healthy tomato plants $[\mathrm{H}(-)]$. 
Table 2. Survey for the detection of TYLCV in selected governorates in Egypt tested by conventional and multiplex PCR

\begin{tabular}{lccccc}
\hline \multirow{2}{*}{ Location } & Infected/tested & \multicolumn{2}{c}{ Single infection } & \multicolumn{2}{c}{ Mixed infection } \\
\cline { 3 - 5 } & & TYLCV-IL & TYLCV-MILD & TYLCV-ES & TYLCV-SIC \\
\hline El Sharkeya & $11 / 11$ & 10 & 1 & 0 & 0 \\
El Qalyoubeya & $9 / 9$ & 9 & 0 & 0 & 0 \\
Kafr El Sheikh & $8 / 9$ & 8 & 0 & 0 & 0 \\
El Giza & $10 / 10$ & 8 & 3 & 0 & 0 \\
El Gharbeya & $9 / 9$ & 7 & 2 & 0 & 0 \\
El Beheira & $15 / 17$ & 14 & 0 & 0 & 0 \\
Alexandria & $0 / 10$ & 0 & 0 & 0 & 0 \\
Damietta & $0 / 5$ & 0 & 0 & 0 & 0 \\
El Dakahlia & $0 / 6$ & 0 & 0 & 0 & 0 \\
El Fayoum & $0 / 4$ & 0 & 0 & 0 & 0 \\
Total & $62 / 90$ & $56 / 90$ & 6 & 0 & 0 \\
\end{tabular}

detection of Italian, Sicilian or Spanish strains of TYLCSV in the surveyed Egyptian governorates.

\section{Molecular characterization of TYLCV isolates in Egypt}

TYLCV genome region containing V1 and V2 genes of 10 Egyptian isolates from different governorates, were subjected to amplification, sequencing and comparison against sequences of isolates available in the GenBank database. Moreover, the full genome of TYLCV-TY10 isolate from Wady El-Natron in El Beheira governorate was amplified and sequenced.

Phylogenetic analysis of $V 1$ and V2 genes from 10 Egyptian TYLCV isolates

Nucleotide sequences of Egyptian TYLCV isolates TY1 to TY10 containing V1 and V2 overlapped genes (1,065 bp) received GenBank Acc. Nos. KT921304 to KT921313, respectively.

A phylogenetic tree was generated by MEGA6 software from alignment based on the nucleotide sequence of the TYLCV Egyptian isolates and sequences of 22 selected isolates available in GenBank (Fig. 4). Egyptian isolates were grouped together in the same branch, except TY3 and TY10 isolates, and showed higher degree of identity ( 98\%) in comparison with the isolate TYLCV-IL from Jordan (GQ861426). A higher phylogenetic distance (identity 96\%) was observed in comparison with CR isolate from Costa Rica (KF533855).

Within the same branch, the TY2 and TY7 isolates from El Qalyoubeya and El Gharbeya governorates, respectively, showed around $98 \%$ of identity with the other Egyptian isolates (TY1, TY4, TY6, TY7, TY9 and TY10) that were grouped in a different sub-cluster. Moreover, isolates TY2 (El Qalyoubeya) and TY6 (Giza) showed lower identity

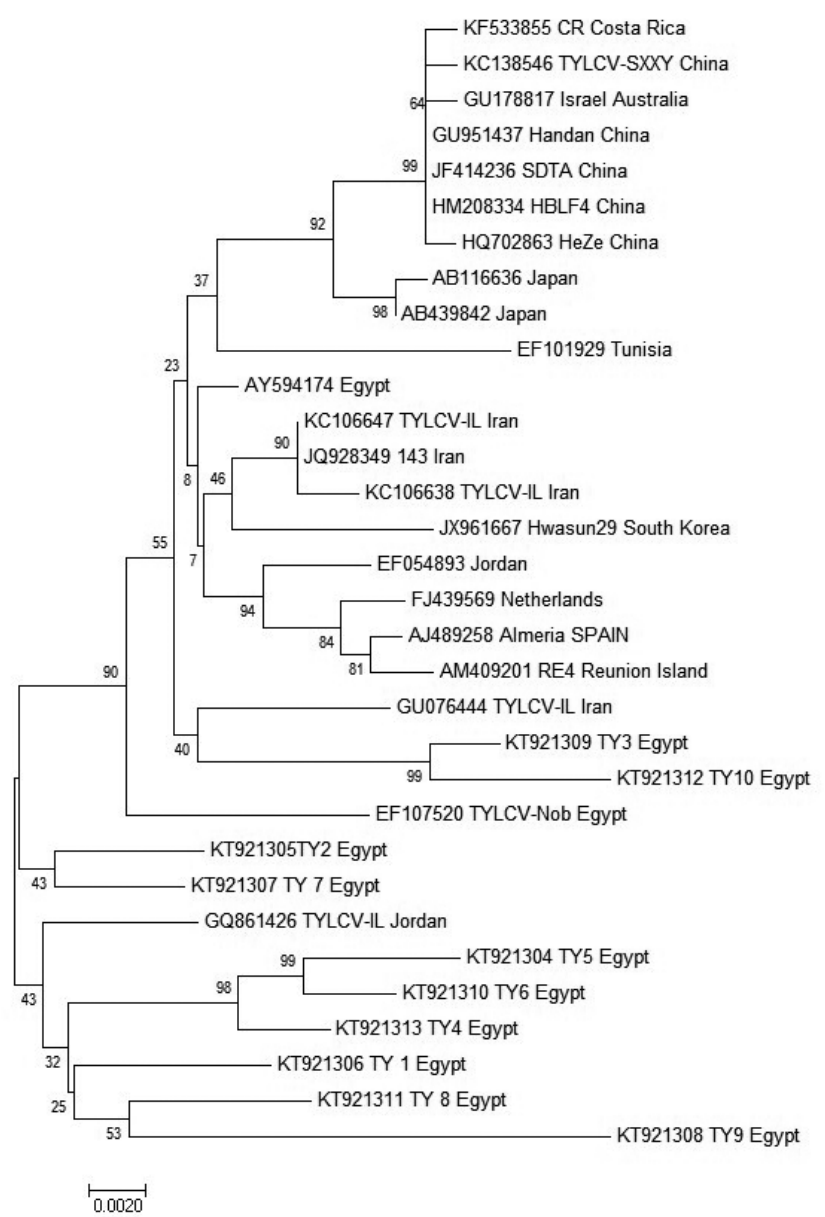

Fig. 4

Phylogenetic analysis of the 10 Egyptian TYLCV isolates based on $\mathrm{V} 1+\mathrm{V} 2$ sequences

Phylogenetic analysis of the 10 Egyptian TYLCV isolates (TY1 to TY10) compared to previously reported TYLCV isolates, according to nucleotide sequences of V1+V2 ORFs. The tree was constructed using the NJ method under the MEGA6 software (Tamura et al., 2013). Bootstrap analysis performed with 1000 replicates. The scale bar shows the number of substitutions per nucleotide. 


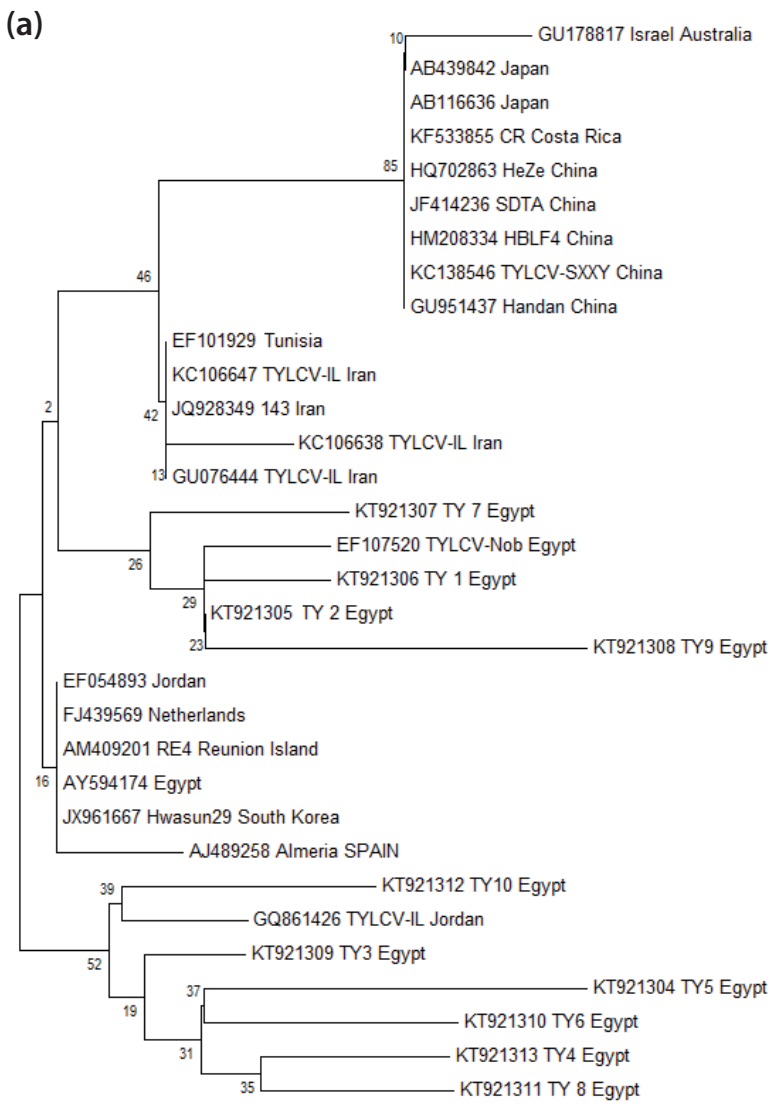

$\widehat{0.0020}$ (b)

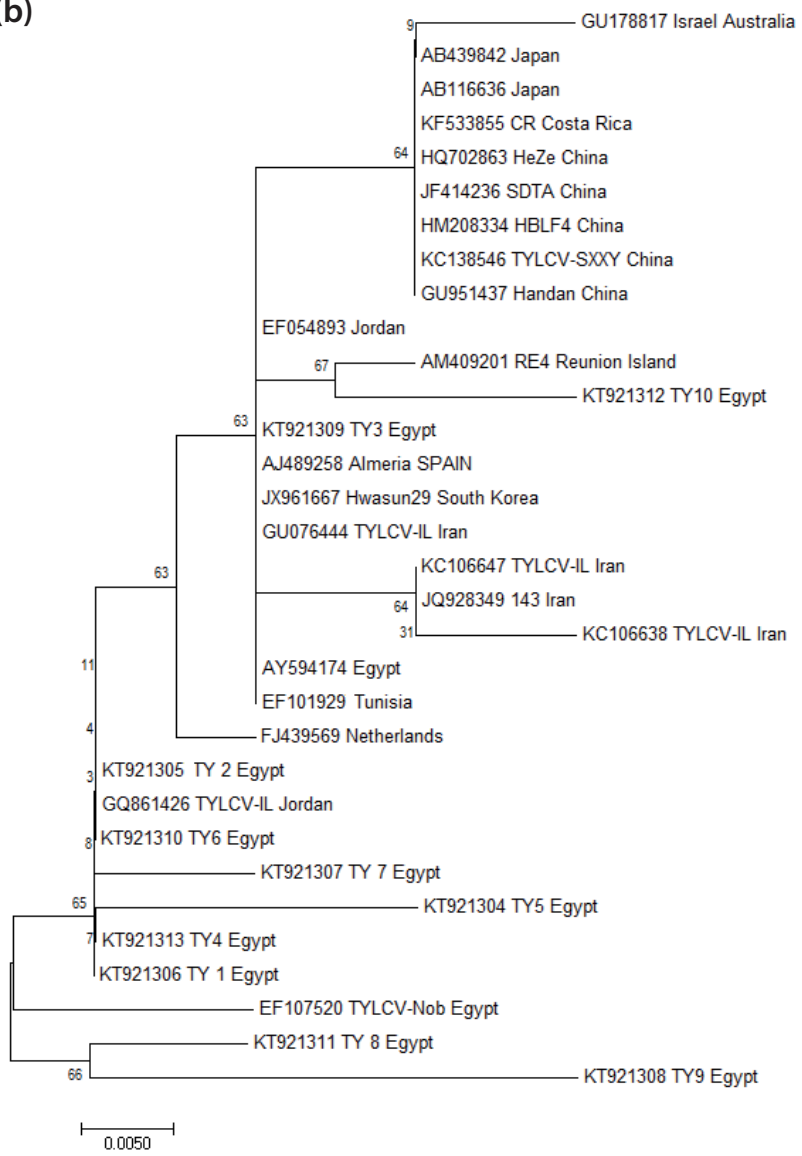

Fig. 5

Phylogenetic analysis of the 10 Egyptian TYLCV isolates based on V1 and V2 sequences

Phylogenetic analysis of the 10 Egyptian TYLCV isolates (TY1 to TY10), compared with previously reported TYLCV isolates, based on amino acid sequences of V1 (a) and V2 (b) ORFs. The tree was constructed using the NJ method under the MEGA6 software (Tamura et al., 2013). Bootstrap analysis performed with 1000 replicates. The scale bar shows the number of substitutions per nucleotide.

( 96\%) within the same branch. The two isolates TY3 and TY10 from Kafr El Sheikh and El Beheira, respectively, grouped together in a different cluster showing the best identity (98\%) in comparison with the isolate TYLCV-IL from Iran (GU076444).

Phylogenetic dendrograms, based on alignment of the deduced amino acid sequences of V2 and V1 genes, were also constructed. For the V1 gene, the Egyptian isolates separated in two distinct clusters (Fig 5a). The first one includes TY1, TY2, TY7, TY9 and the TYLCV-Nob (Egypt, EF107520) isolates that share identity from 97.1 to 98.3\%. In the second cluster TY3 to TY6, TY8 and TY10 grouped together with the isolate TYLCV-IL form Jordan (GQ861426) showing identity from 97.5 to $98.5 \%$. When the V2 gene was analyzed all 10 Egyptian isolates, with the exception of TY3 and TY10, clustered together with the Jordanian (GQ861426) and the Egyptian (EF107520) isolates showing degree of relatedness from 98.0 to $99.7 \%$ (Fig. 5b). The TY3 isolate showed higher identity (99.4\%) with the isolate EF054893 from Jordan while the TY10 isolate was in $98.8 \%$ similar to the RE4 isolate from the Reunion Island (AM409201).

Phylogenetic analysis of full-length genome of TYLCV TY10 isolate

Full-length genome of TYLCV-TY10 Egyptian isolate from a tomato sample collected from Wady El-Natron in El Beheira governorate (hybrid cultivar 1077) was amplified using specific primers (Table 1). The complete genome of the TY10 isolate comprised 2,773 nts (Acc. No. KT921303) showing the typical genome organization of the viral species (Fig. 1). V2 gene (147-497 nts) encodes movement protein, V1 gene (301-1,083 nts) encodes capsid protein while C3 


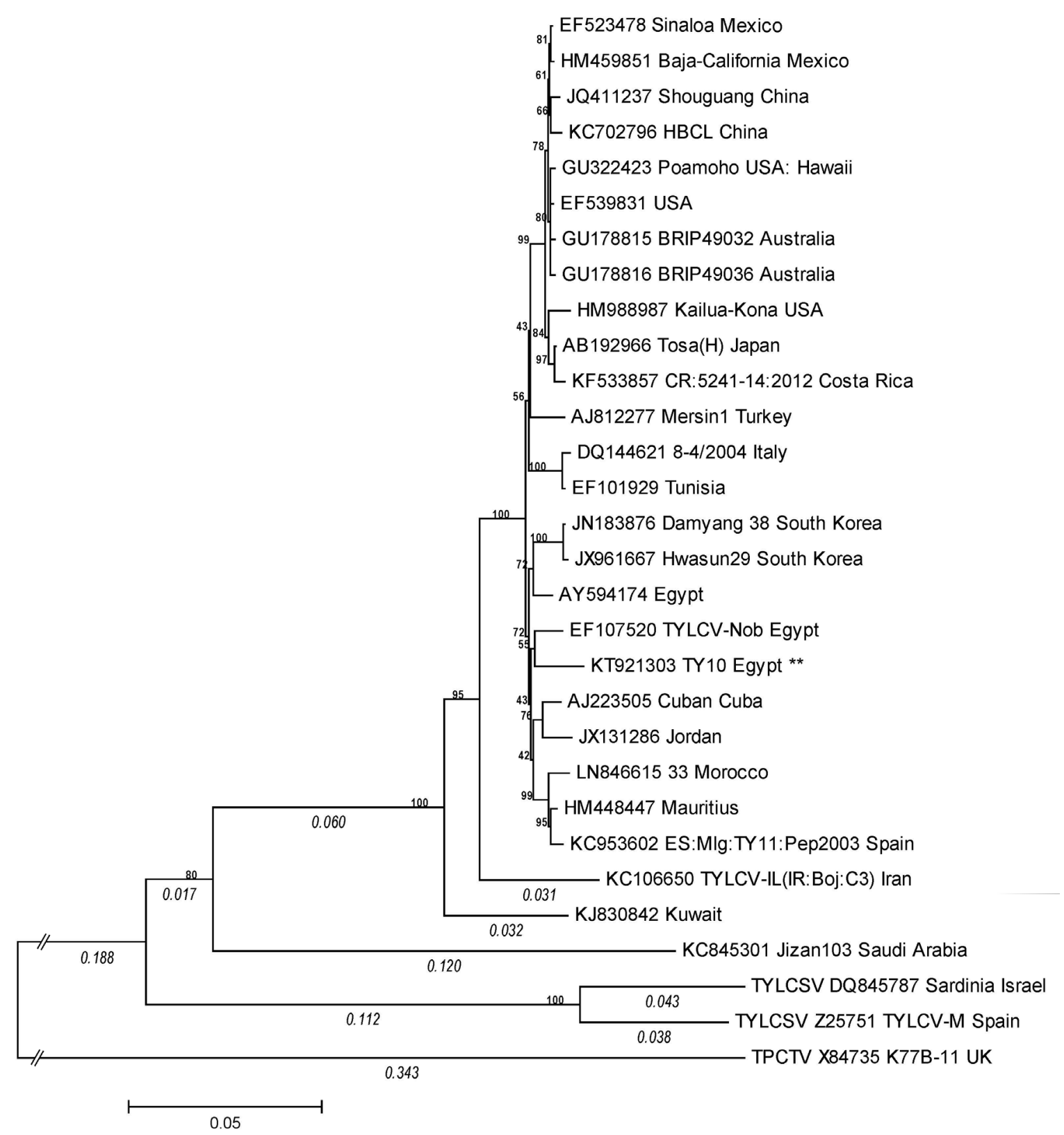

Fig. 6

Phylogenetic analysis of the full-length genome of TYLCV-TY10 Egyptian isolate

Phylogenetic analysis of the full-length genome of TYLCV-TY10 Egyptian isolate compared with previously reported TYLCV isolates based on nucleotide sequence. The tree produced using the NJ method under the MEGA6 package (Tamura et al., 2013). Bootstrap analysis performed with 1000 replicates. The scale bar shows the number of substitutions per nucleotide. Tomato pseudo-curly top virus (TPCTV) was used as outgroup.

(1,080-1,523 nts), C2 (1,225-1,632 nts), C1 (1,541-2,614 nts) and C4 (2,170-2,463 nts) genes encode C1, C2, C3 and C4 proteins, respectively.

The phylogenetic tree generated from alignment based on the nucleotide sequences of full-length genome of TYLCVTY10 isolate and 26 selected isolates available in the Gen-
Bank database was obtained using Neighbor-Joining method and Bootstrap test under the MEGA6 package (Fig. 6). The analysis revealed that the isolate TY10 shares higher degree of relatedness with the Egyptian isolates EF107520 and AY594174 (97.8 and 97.4\%, respectively). Also, phylogenetic identity of $97.6 \%$ was observed between TY10 isolates and 
JX131286 and Tosa (H) (AB192966) isolates from Jordan and Japan, respectively. Among the other TYLCV GenBank sources considered, the TY10 isolate showed a nucleotide identity ranging from 80.0 to $97.4 \%$ comparing with the Jizan103 isolate from Saudi Arabia (KC845301) and the isolate KJ830842 from Kuwait, respectively. The tomato pseudocurly top virus (TPCTV) sequence was used as outgroup.

\section{Discussion}

TYLCD is a disease complex of increasing concern for tomato growers in many regions of the world (Guindon and Gascuel, 2003; Khan et al., 2008; Fazeli et al., 2009; Garc1'aAndre's et al., 2007). TYLCV is known to infect tomato in Egypt and in the last three years, the incidence of infection was very high. During the survey visual estimates of infection by TYLCV was up to $100 \%$ in some areas. Symptoms of leaf curling, yellowing and stunted growth are very characteristic for the infection. It is known that the virus exists in the Mediterranean area in several strains also. Characterization of TYLCV potential strains causing infection was by strain specific primer sets in PCR

Under natural conditions, single and mixed infection occurs and each may lead to the production of new viral genetic variation in the population (Rojas et al., 1993; Padidam et al., 1999; Khan et al., 2013). Our results reported an overall detection percentage of TYLCV higher than $72 \%$. TYLCVIL was more predominant strain, while TYLCV-Mild was present in the $6.6 \%$ of the samples. Mixed infections were detected in several areas confirming the genetic variability of the population as previously reported in several studies (Anfoka et al., 2005; Anfoka et al., 2008; Hajimorad et al., 1996; Owor et al., 2007). This may lead to a synergistic rather than a cross protection effect (Morilla et al., 2004). The Mediterranean basin has been identified as the main launch pad of global TYLCV movements (Lefeuvre et al., 2010; Fauquet et al., 2005). As high diversity degree of the virus has been reported also in the Middle East (Bananej et al., 2004; Khan et al., 2008), we decided to develop and use in our analyses a more sensitive detection method based on real-time PCR. Results confirmed higher sensitivity of realtime PCR technique that identified $72.2 \%$ of infected samples in comparison with $68.8 \%$ of those detected by conventional PCR. More interestingly, the real-time PCR assay was able to differentiate, simply by dissociation analysis, between the two most abundant TYLCV-IL and TYLCV-Mild strains and therefore demonstrate to be a reliable tool to investigate TYLCD etiology. Both strains have the broadest geographical ranges stretching in the Old World from Japan in the east (Sugiyama et al., 2008), Spain in the west (Navas-Castillo et al., 1999), the Indian Ocean island of Reunion (Peterschmitt et al., 1999) and Australia (Stonor et al., 2003) in the south.
According to Lefeuvre et al. (2010) TYLCV has jumped at least twice between the Old and New world (McGlashan et al., 1994; Duffy and Holmes, 2007) and is currently in North and South America (Zambrano et al., 2007; Czosnek and Laterrot, 1997). TYLCV-IL is therefore considered to have an unusually large geographical range.

Our results indicate a high infection rate of the virus in Egypt. It points to a significant degree of diversity at both the nucleotide and the amino acid levels of V1 and V2 genes within the ten Egyptian TYLCV-IL isolates. V1 and $\mathrm{V} 2$ genes are less affected by amino acid changes than other genes (Yang et al., 2014) but at the nucleotide level TY3 and TY10 were more similar to TYLCV-IL (GUO76444) isolate from Iran than to the other Egyptian isolates analyzed. Moreover, amino acid analysis of V1 gene suggests the presence of two main TYLCV clusters in Egypt while V2 gene analysis confirms the distance of TY3 and TY10 from the other Egyptian isolates.

In order to improve knowledge about genetic assessment of TYLCV population in Egypt, the complete genome of TY10 isolate (2,373 nts) has been sequenced and compared to previously reported sequences of Egyptian isolates (Abdallah et al., 2000; Abhary et al., 2006). Phylogenetic analysis of the sequences has shown that TY10 has a close degree of relatedness to the other Egyptian isolates but also to Jordanian and Japanese isolates.

Phylogenetic analysis conducted on V1+V2 genes from ten isolates and on the complete genome of TY10 isolate may suggest a multiple introduction of TYLCV to Egypt due to the increasing international exchange of plant material. Moreover, high variability among Geminivirus genomes in progeny populations was reported over a short period of time (Yang et al., 2014). The East African cassava mosaic virus (EACMV) (Geminivirus genus) has shown mean rates of $1.60 \times 10^{-3}$ and $1.53 \times 10^{-4}$ nucleotide substitutions per site per year for DNA-A and DNA-B components respectively (Duffy and Holmes, 2009). Considering the continuous genetic variations of the virus our results suggest that also in Egypt the mean substitution rate of the virus could be 2.88 $\mathrm{x} 10^{-4}$ nucleotide per site per year as estimated in previous studies independently by the recombination frequency of the virus (Duffy and Holmes, 2008). This may lead to the production of isolates acquiring traits for being more virulent to plant infection or allows co-transmission of more than one isolate by the whitefly vector (Ohnishi et al., 2011).

Continuous monitoring of TYLCV isolate sequences is therefore necessary to the understanding of this virus complex epidemiology and spread. This also is fundamental to the proper application of management strategies of the disease. In fact, the dissemination of tolerant cultivars in case of TYLCD has more safety impact than the release of genetically modified plants (Morilla et al., 2004) due to the genetic diverging of TYLCV isolates. 
Acknowledgement. This work has been funded by the Science and Technology Development Fund (STDF), Egypt, project I.D. 5564.

Supplementary information is available in the online version of the paper.

\section{References}

Abdallah NA, Fauquet CM, Beachy RN, Madkour MA (2000): Cloning and constructing infectious clones of an Egyptian isolate of tomato yellow leaf curl virus. Arab. J. Biotechnol. 3, 35-54.

Abhary MK, Anfoka GH, Nakhla MK, Maxwell DP (2006): Posttranscriptional gene silencing in controlling viruses of the tomato yellow leaf curl virus complex. Arch. Virol. 151, 2349-2363. https://doi.org/10.1007/s00705-006-0819-7

Accotto GP, Navas-Castillo J, Noris E, Moriones E, Louro D (2000): Typing of tomato yellow leaf curl viruses in Europe. European J. Plant Pathol. 106, 179-186. https://doi. org/10.1023/A:1008736023293

Accotto GP, Bragaloni M, Luison D, Davino S, Davino M (2003): First report of tomato yellow leaf curl virus (TYLCV) in Italy. Plant Pathol. 52, 799-799. https://doi.org/10.1111/ j.1365-3059.2003.00908.x

Anfoka GH, Abhary M, Nakhla MK (2005): Molecular identification of species of the tomato yellow leaf curl virus complex in Jordan. J. Plant Pathol. 87, 61-66.

Anfoka G, Abhary M, Haj Ahmad F, Hussein AF, Rezk A, Akad F, Abou-JawdahY, Lapidot M, Vidavski F, Nakhla MK, Sobh H, Atamian H, Cohen L, Sobol I, Mazyad H., Maxwell DP, Czosnek H (2008): Survey of tomato yellow leaf curl disease-associated viruses. J. Plant Pathol. 90, 313-322.

Arupratan D, Subodh KS, Shelly P (2004): Structure of replication initiator protein unites diverse viruses causing tomato leaf curl disease (ToLCD). Plant Sci. 166, 1063-1067. https:// doi.org/10.1016/j.plantsci.2003.12.024

Bananej K, Kheyr-Pour A, Salekdeh GH, Ahoonmanesh A (2004): Complete nucleotide sequence of Iranian tomato yellow leaf curl virus isolate: further evidence for natural recombination amongst Begomoviruses. Arch. Virol. 149, 1435-1443. https://doi.org/10.1007/s00705-004-0308-9

Barboza N, Blanco-Meneses M, Hallwass M, Moriones E, InoueNagat AK (2014): First Report of tomato yellow leaf curl virus in tomato in Costa Rica. Plant Dis. 98, 699 https:// doi.org/10.1094/PDIS-08-13-0881-PDN

Botermans M, Verhoeven JTJ, Jansen CCC, Roenhorst JW, Stijger CCMM, Pham KTK (2009): First Report of tomato yellow leaf curl virus in tomato in the Netherlands. Plant Dis. 93 (10), 1073. https://doi.org/10.1094/pdis-93-10-1073c

Briddon RW, Bedford ID, Tsai JH, Markham PG (1996): Analysis of the nucleotide sequence of the treehopper-transmitted Geminivirus, tomato pseudo-curly top virus, suggests a recombinant origin. Virology 219, 387-394. https://doi. org/10.1006/viro.1996.0264

Brown JK, Idris AM (2008): Introduction of the exotic monopartite tomato yellow leaf curl virus into west coast Mexico. Plant Dis. 90, 1360. https://doi.org/10.1094/PD-90-1360A
Cardenas-Conejo Y, Arguello-Astorga G, Poghosyan A, HernandezGonzalez J, Lebsky V, Holguin J, Medina-HernandezD, Vega S (2010): First report of tomato yellow leaf curl virus co-infecting pepper with tomato chino La Paz virus in Baja California Sur, Mexico. Plant Dis. 94, 1266. https:// doi.org/10.1094/PDIS-06-10-0444

Czosnek H, Ghanim M (2011): Bemisiatabaci-tomato yellow leaf curl virus interaction causing worldwide epidemics. In: Thompson, W.M.O. (Ed.), the whitefly, Bemisiatabaci (Homoptera: Aleyrodidae) interaction with Geminivirus infected host plants. Springer, Dordrecht, 51-61.

Czosnek H, Laterrot H (1997): A worldwide survey of tomato yellow leaf curl viruses. Arch. Virol. 142, 1391-1406. https://doi. org/10.1007/s007050050168

Delatte H, Holota H, Naze F, Peterschmitt M, Reynaud B, Lett JM (2005): The presence of both recombinant and nonrecombinant strains of tomato yellow leaf curl virus on tomato in Reunion Island. Plant Pathol. 54, 262-262. https://doi.org/10.1111/j.1365-3059.2004.01154.x

Duffy S, Holmes EC (2007): Multiple introductions of the Old World Begomovirus tomato yellow leaf curl virus into the New World. Appl. Environ. Microbiol. 73, 7114-7117. https://doi.org/10.1128/AEM.01150-07

Duffy S, Holmes EC (2008): Phylogenetic evidence for rapid rates of molecular evolution in the single-stranded DNA Begomovirus tomato yellow leaf curl virus. J. Virol. 82, 957-965. https://doi.org/10.1128/JVI.01929-07

Duffy S, Holmes EC (2009): Validation of high rates of nucleotide substitution in Geminiviruses: phylogenetic evidence from East African cassava mosaic viruses. J. Gen. Virol. 90, 1539-1547. https://doi.org/10.1099/vir.0.009266-0

Fauquet CM, Sawyer S, Idris AM, Brown JK (2005): Sequence analysis and classification of apparent recombinant Begomoviruses infecting tomato in the Nile and Mediterranean basins. Phytopathology 95, 549-555. https://doi. org/10.1094/PHYTO-95-0549

Fazeli R, Heydarnejad J, Massumi H, Shaabanian M, Varsani A (2009): Genetic diversity and distribution of tomato-infecting Begomoviruses in Iran. Virus Genes 38, 311-319. https://doi.org/10.1007/s11262-008-0310-5

Garc1'a-Andre's S, Accotto GP, Navas-Castillo J, Moriones E (2007): Founder effect, plant host, and recombination shape the emergent population of Begomoviruses that cause the tomato yellow leaf curl disease in the Mediterranean basin. Virology 359, 302-312. https://doi.org/10.1016/j. virol.2006.09.030

GharsallahChouchane S, Gorsane F, Nakhla MK, Maxwell DP, Marrakchi M, Fakhfakh H (2007): First report of tomato yellow leaf curl virus -Israel species infecting tomato, pepper and bean in Tunisia. J. Phytopathol. 155, 236-240. https://doi.org/10.1111/j.1439-0434.2007.01224.X

Glick E, Zrachya A, Levy Y, Mett A, Gidoni D, Belausov E, Citovsky V, Gafni Y (2008): Interaction with host SGS3 is required for suppression of RNA silencing by tomato yellow leaf curl virus V2 protein. Proc. Natl. Acad. Sci. USA 105, 157-161. https://doi.org/10.1073/pnas.0709036105

Guindon S, Gascuel O (2003): A simple, fast, and accurate algorithm to estimate large phylogenies by maxi- 
mum likelihood. Syst. Biol. 52, 696-704. https://doi. org/10.1080/10635150390235520

Hajimorad M, KheyrPour A, Alavi V, Ahoonmanesh A, Bahar M, Rezaian MA, Gronenborn B (1996): Identification of whitefly transmitted tomato yellow leaf curl Geminivirus from Iran and a survey of its distribution with molecular probes. Plant Pathol. 45, 418-425. https://doi. org/10.1046/j.1365-3059.1996.d01-151.x

Hormuzdi SG, Bisaro DM (1995): Genetic analysis of beet curl top virus: Examination of the roles of $\mathrm{L} 2$ and $\mathrm{L} 3$ genes in viral pathogenesis. Virolology 206, 1044-1054. https:// doi.org/10.1006/viro.1995.1027

Hosseinzadeh MR, Shams-Bakhsh M, Osaloo SK, Brown JK (2014): Phylogenetic relationships, recombination analysis, and genetic variability among diverse variants of tomato yellow leaf curl virus in Iran and the Arabian Peninsula: further support for a TYLCV center of diversity. Arch. Virol. 159, 485-497. https://doi.org/10.1007/s00705013-1851-Z

Jiang L, Wei, CH, Li Y (2012): Viral suppression of RNA silencing. Sci. China C. Life Sci. 55, 109-118. https://doi. org/10.1007/s11427-012-4279-X

Khan AJ, Idris AM, Al-Saady NA, Al-Mahruki MS, Al-Subhi AM., Brown J K. (2008): A divergent isolate of tomato yellow leaf curl virus from Oman with an associated DNA beta satellite: an evolutionary link between Asian and the Middle Eastern virus-satellite complexes. Virus Genes 36, 169-176. https://doi.org/10.1007/s11262-007-0163-3

Khan AJ, Akhtar S, Singh AK, Briddon RW (2013): A distinct strain of tomato leaf curl Sudan virus causes tomato leaf curl disease in Oman. Plant Dis. 97, 1396-1402. https://doi. org/10.1094/PDIS-02-13-0210-RE

Koklu G, Rojas A, Kvarnheden A (2006): Molecular identification and the complete nucleotide sequence of a tomato yellow leaf curl virus isolate from Turkey. J. Plant Pathol. 88, 61-66.

Lefeuvre P, Martin DP, Harkins G, Lemey P, Gray AJA, Meredith S, Lakay L, Monjane A, Lett JM, Varsani A, Heydarnejad J (2010): The spread tomato yellow leaf curl virus from the Middle East to the World. PLoSPathog 6, e1001164. https://doi.org/10.1371/journal.ppat.1001164

Lobin K, Druffel KL, Pappu HR, Benimadhu SP (2010): First report of tomato yellow leaf curl virus in tomato in Mauritius. Plant Dis. 94, 1261. https://doi.org/10.1094/PDIS-0110-0030

McGlashan D, Polston J Bois D (1994): tomato yellow leaf curl Geminivirus in Jamaica. Plant Dis. 78, 1219-1219. https:// doi.org/10.1094/PD-78-1219C

Melzer M J, Ogata DY, Fukuda SK, Shimabuku R., Borth WB, Sether DM, Hu JS (2010): First Report of tomato yellow leaf curl virus in Hawaii. Plant Dis. 94, 641. https://doi. org/10.1094/PDIS-94-5-0641B

Morilla G, Krenz B, Jeske H, Bejarano ER, Wege C (2004): Tête a’ Tête of tomato yellow leaf curl virus s and tomato yellow leaf curl Sardinia virus in single nuclei. J. Virol. 78, 10715-10723. https://doi.org/10.1128/JVI.78.19.10715$\underline{10723.2004}$

Morilla G, Janssen D, Garcia-Andres S, Moriones E, Cuadrado IM, Bejarano ER (2005): Pepper (Capsicum annuum)
Is a dead-end host for tomato yellow leaf curl virus. Phytopathology 95, 1089-1097. https://doi.org/10.1094/ PHYTO-95-1089

Moriones E, Navas-Castillo J (2000): Tomato yellow leaf curl virus, an emerging virus complex causing epidemics worldwide. Virus Res. 71, 123-134. https://doi.org/10.1016/S0168$\underline{1702(00) 00193-3}$

Nakhla MK, Maxwell DP (1998): Epidemiology and management of tomato yellow leaf curl disease. In Hadidi A, Khetarpal R.K, Koganezawa H. (Eds): Plant Virus Disease Control. APS Press, St. Paul, MN, USA, pp. 565-583.

Nakhla MK, Mazyad HM, Maxwell DP (1993): Molecular characterization of four tomato yellow leaf curl virus isolates from Egypt and development of diagnostic method. Phytopathol. Medit. 32, 163-173.

Navas-Castillo J, Sanchez-Campos S, Diaz J, Saez-Alonso E, Moriones $\mathrm{E}$ (1999): tomato yellow leaf curl virus -is causes a novel disease of common bean and severe epidemics in tomato in Spain. Plant Dis. 83, 29-32. https://doi. org/10.1094/PDIS.1999.83.1.29

Noris E, Hidalgo E, Accotto GP, Moriones E (1994): High similarity among the tomato yellow leaf curl virus isolates from the west Mediterranean basin: the nucleotide sequence of an infectious clone from Spain. Arch.Virol. 135, 165-170. https://doi.org/10.1007/bf01309774

Nour El-Din F, Mazyad HM, Hassan MS (1969). tomato yellow leaf curl virus disease. Agric. Res. Rev. Cairo 47, 49-51.

Ohnishi J, Kitamura T, Terami F, Honda K (2011): Co-transmission of tomato yellow leaf curl virus (TYLCV)-Mld and TYLCV-IL by the whitefly Bemisiatabaci. J. Gen. Plant Pathol. 77, 54-59. https://doi.org/10.1007/s10327-010-0277-7

Owor BE, Shepherd DN, Taylor NJ, Edema R, Monjane AL, Thomson JA, Martind D P, Varsani A(2007): Successful application of FTA Classic Card technology and use of bacteriophage phi29 DNA polymerase for large-scale field sampling and cloning of complete maize streak virus genomes. J. Virol. Methods 140, 100-105. https:// doi.org/10.1016/j.jviromet.2006.11.004

Padidam M, Sawyer S, Fauquet CM (1999): Possible emergence of new Geminiviruses by frequent recombination. Virology 265, 218-225. https://doi.org/10.1006/viro.1999.0056

Peterschmitt M, Granier M, Mekdoud R, Dalmon A, Gambin O, Vayssieres JF, ReynaudB (1999): First report of tomato yellow leaf curl virus in Reunion Island. Plant Dis. 83, 303-303. https://doi.org/10.1094/PDIS.1999.83.3.303B

Rojas MR, Gilbertson RL, Russell DR, Maxwell DP (1993): Use of degenerate primers in the polymerase chain reaction to detect whitefly-transmitted Geminiviruses. Plant Dis. 77, 340-347. https://doi.org/10.1094/PD-77-0340

Rojas MR, Kon T, Natwick ET, Polston JE, Akad F, Gilbertson RL (2007): First report of tomato yellow leaf curl virus associated with tomato yellow leaf curl disease in California. Plant Dis. 91, 1056. https://doi.org/10.1094/ PDIS-91-8-1056A

Rybicki EP, Briddon RW, Brown JE, Fauquet CM, Maxwell DP, Harrison BD, Markham PG, Bisaro DM, Robinson D, Stanley J (2000): Geminiviridae. In van Regenmortel MHV, Fauquet CM, Bishop DHL, Carstens EB, Lemon 
SM, Maniloff J, Mayo MA, Mc-Geoch DJ, Wickner RB (Eds): Virus Taxonomy. Seventh Report of the International Committee on Taxonomy of Viruses. Academic Press, San Diego, USA, pp. 285-297.

Selth LA, Randles JW, Rezaian MA (2004): Host responses to transient expression of individual genes encoded by tomato leaf curl virus. Mol. Plant Microbe Interact. 17, 27-34. https://doi.org/10.1094/MPMI.2004.17.1.27

Stonor J, Hart P, Gunther M, DeBarro P, Rezaian M (2003): Tomato leaf curl Geminivirus in Australia: occurrence, detection, sequence diversity and host range. Plant Pathol. 52, 379388. https://doi.org/10.1046/j.1365-3059.2003.00854.x

Sugiyama K, Matsuno K, Doi M, Tatara A, Kato M, Tagami Y. (2008): TYLCV detection in Bemisiatabaci (Gennadius) (Hemiptera: Aleyrodidae) B and Q biotypes, and leaf curl symptom of tomato and other crops in winter greenhouses in Shizuoka Pref., Japan. Appl. Entomol. Zool. 43, 593-598. https://doi.org/10.1303/aez.2008.593

Tamura K, Stecher G, Peterson D, Filipski A, Kumar S (2013): MEGA6: Molecular evolutionary genetics analysis version 6.0. Mol. Biol. Evol. 30, 2725-2729. https://doi. org $/ 10.1093 / \mathrm{molbev} / \mathrm{mst} 197$
Ueda S, Kimura T, Onuki M, Hanada K, Iwanami T (2004): Three distinct groups of isolates of tomato yellow leaf curl virus in Japan and construction of an infectious clone. J. Gen. Plant Pathol. 70, 232-238. https://doi.org/10.1007/ $\underline{\text { s10327-003-0112-5 }}$

Ueda S, Takeuchi S, Okabayashi M, Hanada K, Tomimura K, Iwanami T (2005): Evidence of a new tomato yellow leaf curl virus in Japan and its detection using PCR. J. Gen. Plant Pathol. 71, 319-325. https://doi.org/10.1007/ $\underline{\text { s10327-005-0202-7 }}$

Yang X, Zhou, Qian Y, Xie Y, Zhou X (2014): Molecular variability and evolution of a natural population tomato yellow leaf curl virus in Shanghai, China. J. Zhejiang Univ.-Sci. B. (Biomed. \& Biotechnol.) 15, 133-142.

Zambrano K, Carballo O, Geraud F, Chirinos D, Fernandez C, Marys E (2007): First report of tomato yellow leaf curl virus in Venezuela. Plant Dis. 91, 768-768. https://doi. org/10.1094/PDIS-91-6-0768A

Zhou XP, Xie Y, Zhang ZK (2001): Molecular characterization of a distinct Begomovirus infecting tobacco in Yunnan, China. Arch. Virol. 146, 1599-1606. https://doi. org/10.1007/s007050170081 


\title{
Supplementary information
}

\section{Detection and molecular characterization of tomato yellow leaf curl virus naturally infecting Lycopersicon esculentum in Egypt}

\author{
M. RABIE ${ }^{1}$, C. RATTI ${ }^{2}$, E. ABDEL ALEEM ${ }^{1}$, F. FATTOUH ${ }^{1}$ \\ ${ }^{1}$ Botany and Microbiology, Department Faculty of Science, Alexandria University, Alexandria, Egypt; ${ }^{2}$ DipSA-Patologia Vegetale, \\ Università di Bologna, Viale G. Fanin, 40-40127 Bologna, Italy
}

Received September 30, 2016; revised November 7, 2016; accepted June 5, 2017

Supplementary Table S1. Reference TYLCV sequences and their DDBJ/EMBL/GenBank Acc. Nos. used in phylogenetic analysis

\begin{tabular}{|c|c|c|c|c|}
\hline Sequence reference & Original host & $\begin{array}{l}\text { Geographic } \\
\text { origin }\end{array}$ & Isolate & Acc. No. \\
\hline \multicolumn{5}{|c|}{ V1 and V2 gene sequences of TYLCV isolates } \\
\hline NCBI & Solanum lycopersicum & Jordan & TYLCV-IL & GQ861426 \\
\hline Abhary et al.(2006) & not stated & Egypt & - & AY594174 \\
\hline Lefeuvre et al. (2010) & Solanum lycopersicum & Iran & TYLCV-IL & GU076444 \\
\hline Botermans et al. (2009) & Solanum lycopersicum & Netherlands & 3181291 & FJ439569 \\
\hline NCBI & not stated & Jordan & - & EF054893 \\
\hline Morilla et al. (2005) & Capsicum anuum & Spain & Almeria & AJ489258 \\
\hline Hosseinzadeh et al. (2014) & Datura stramonium & Iran & TYLCV-IL & KC106647 \\
\hline NCBI & Solanum lycopersicum & Iran & 143-Bojnord & JQ928349 \\
\hline NCBI & Solanum lycopersicum & China & $\mathrm{HeZe}$ & HQ702863 \\
\hline Delatte et al.(2005) & Solanum lycopersicum & Reunion & RE4 & AM409201 \\
\hline Barboza et al. (2014) & Solanum lycopersicum & Costa Rica & CR:5240-16:2012 & KF533855 \\
\hline Hosseinzadeh et al. (2014) & Datura stramonium & Iran: Bojnurd & TYLCV-IL & KC106638 \\
\hline NCBI & Solanum lycopersicum & China & SDTA & JF414236 \\
\hline NCBI & - & China & HBLF4 & HM208334 \\
\hline NCBI & Solanum lycopersicum & Australia & BRIP49041 & GU178817 \\
\hline NCBI & Solanum lycopersicum & China & Handan & GU951437 \\
\hline Ueda et al. (2004) & Solanum lycopersicum & Japan & - & AB116636 \\
\hline NCBI & Solanum lycopersicum & China & TYLCV-SXXY & KC138546 \\
\hline NCBI & Tomato & South Korea & Hwasun29 & JX961667 \\
\hline NCBI & not stated & Japan & - & AB439842 \\
\hline Gharsallah Chouchane et al. (2007) & not stated & Tunisia & - & EF101929 \\
\hline Abdallah et al. (2000) & not stated & Egypt & TYLCV-Nob & EF107520 \\
\hline \multicolumn{5}{|c|}{ Full length genome sequences of TYLCV isolates } \\
\hline Ueda et al. (2005) & Lycopersicon esculentum & Japan & Tosa & AB192965 \\
\hline NCBI & not stated & Cuba & Cuban & AJ223505 \\
\hline Koklu et al. (2006) & Lycopersicon esculentum & Turkey & Mersin 1 & AJ812277 \\
\hline Abhary et al.(2006) & not stated & Egypt & - & AY594174 \\
\hline Accotto et al. (2003) & Lycopersicon esculentum & Italy: Sicily & $8-4 / 2004$ & DQ144621 \\
\hline
\end{tabular}




\begin{tabular}{|c|c|c|c|c|}
\hline Sequence reference & Original host & $\begin{array}{l}\text { Geographic } \\
\text { origin }\end{array}$ & Isolate & Acc. No. \\
\hline NCBI & not stated & Tunisia & - & EF101929 \\
\hline Abdallah et al. (2000) & Tomato & Egypt & TYLCV-Nob & EF107520 \\
\hline NCBI & not stated & Mexico & Sinaloa & EF523478 \\
\hline Rojas et al. (2007) & not stated & USA & - & EF539831 \\
\hline NCBI & $\begin{array}{l}\text { Solanum lycopersicum cv. } \\
\text { Temptation }\end{array}$ & Australia & BRIP49032 & GU178815 \\
\hline NCBI & Solanum lycopersicum & Australia & BRIP49036 & GU178816 \\
\hline Melzer et al. (2010) & Lycopersicon esculentum & USA: Hawaii & Poamoho & GU322423 \\
\hline Lobin et al. (2010) & Tomato & Mauritius & Mauritius & HM448447 \\
\hline Cardenas-Conejo et al. (2010) & Capsicum anпuum & Mexico & Baja-California & HM459851 \\
\hline NCBI & Solanum lycopersicum & USA & Kailua-Kona & HM988987 \\
\hline NCBI & Tomato & South Korea & Damyang 38 & JN183876 \\
\hline NCBI & Capsicum anпuum & China & Shouguang & JQ411237 \\
\hline NCBI & Sinapisarvensis & Jordan & - & JX131286 \\
\hline NCBI & Tomato & South Korea & Hwasun29 & JX961667 \\
\hline Hosseinzadeh et al. (2014) & tomato & Iran & TYLCV-IL(IR:Boj:C3) & KC106650 \\
\hline NCBI & Lycopersicon esculentum & China & HBCL & KC702796 \\
\hline NCBI & Lycopersicon lycopersicum & Saudi Arabia & Jizan 103 & KC845301 \\
\hline NCBI & Capsicum annuum & Spain & ES:Mlg:TY11:Pep2003 & KC953602 \\
\hline Barboza et al. (2014) & Solanum lycopersicum & Costa Rica & CR:5241-14:2012 & KF533857 \\
\hline NCBI & Tomato & Kuwait & - & KJ830842 \\
\hline This work & Tomato & Egypt & TY10 & KT921303 \\
\hline NCBI & Solanum lycopersicum & Morocco & 33 & LN846615 \\
\hline NCBI & not stated & Israel & Sardinia & TYLCSV DQ845787 \\
\hline Noris et al. (1994) & Lycopersicon esculentum & Spain & TYLCV-M & TYLCSV Z25751 \\
\hline Briddon et al. (1996) & Solanum nigrum & $\mathrm{UK}$ & K77B-11 & TPCTV X84735 \\
\hline
\end{tabular}

